\title{
Zirconium isotopic composition of the mantle through time
}

\author{
S.Y. Tian ${ }^{1}$, F. Moynier ${ }^{1 *}$, E.C. Inglis ${ }^{1}$, J. Creech $^{1,2}$, M. Bizzarro ${ }^{1,3}$, \\ J. Siebert ${ }^{1,4}$, J.M.D. Day ${ }^{1,5}$, I.S. Puchtel ${ }^{6}$
}

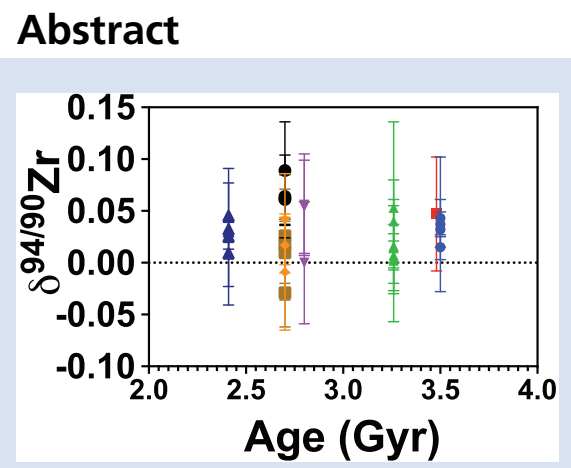

a conservative $\delta^{94 / 90} \mathrm{Zr}=0.040+0.044 \%(\mathrm{n}=7$ magma ocean crystallisation processes. However, their Zr isotope compositions are indistinguishable from other komatiites, implying that bridgmanite crystallisation did not fractionate $\mathrm{Zr}$ isotopes to any measurable extent.

Received 19 May 2020 | Accepted 7 September 2020 | Published 7 October 2020

\section{Introduction}

Zirconium is a refractory element (Tc $=1741 \mathrm{~K}$; Lodders, 2003), and its abundance and stable isotopic composition is, a priori, robust to evaporation processes that occurred during planetary formation. This makes $\mathrm{Zr}$ distinct from more volatile elements, like Zn (Moynier et al., 2017) or even Si and Mg (Pringle et al., 2014; Hin et al., 2017). As with other high field strength elements, $\mathrm{Zr}$ is lithophile and incompatible (Woodhead et al., 1993; Johnson, 1998) and is enriched in the continental crust (Rudnick and Gao, 2003). Zirconium isotopes fractionate during magmatic differentiation. For example, the most evolved lavas from Hekla volcano, Iceland, have a ${ }^{94} \mathrm{Zr} /{ }^{90} \mathrm{Zr}$ ratio $0.5 \%$ higher than less evolved lavas. This is interpreted to reflect differences in coordination of zirconium between zircon and melt (Inglis et al., 2019). Because of the resistance of zircons to physical and chemical abrasion and the availability of other isotope tracers (e.g., $\mathrm{O}$, $\mathrm{Hf}$ ) and elements within them (e.g., rare earth elements), they have found widespread application in the study of Earth's crust through time (Condie, 2005). The isotopic fractionation of $\mathrm{Zr}$ between granites and basalts (Inglis et al., 2018) suggests that $\mathrm{Zr}$ isotopes could be used as tracers within zircons, and of crustal recycling in Earth's mantle, especially since $\mathrm{Zr}$ is a fluid immobile element and should be efficiently recycled into the mantle.
Presently, the Zr isotopic composition of the mantle is estimated by the analysis of relatively low degree basaltic partial melts (Inglis et al., 2019).

Komatiites are ultramafic volcanic rocks with $>18 \mathrm{wt}$. \% $\mathrm{MgO}$. They are formed by partial melting in hot mantle plumes, mostly during the Archean (e.g., Arndt et al., 2008). Since komatiites are mantle-derived high degree partial melts (>30 \%) (Herzberg, 1992), and Zr is moderately incompatible, almost all $\mathrm{Zr}$ from the mantle source is efficiently extracted into komatiitic melts. As such, komatiitic melts must faithfully reflect the $\mathrm{Zr}$ isotopic composition of their mantle source. Similar logic has been used to estimate the composition of the mantle through time of several other elements, including Ca (Amsellem et al., 2019), Ga (Kato et al., 2017), and Ti (Greber et al., 2017; Deng et al., 2018).

Komatiites span a range of ages and, thus, provide the potential to investigate initial mantle composition and, in particular, the processes of crystallisation of an early terrestrial magma ocean (Puchtel et al., 2013, 2016b; Byerly et al., 2017). For example, some komatiites from the Weltevreden formation in the Barberton Greenstone Belt, South Africa, have unusual Ca isotopic compositions compared with other komatiites and are interpreted as a record of mantle source heterogeneities induced

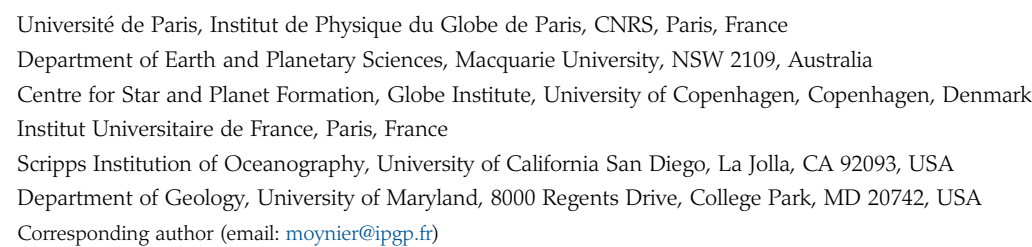


by magma ocean crystallisation (Amsellem et al., 2019). Zirconium is useful to search for traces of magma ocean crystallisation processes because it is compatible in bridgmanite ( $D_{\text {bridgmanite-melt }}>1$; Corgne et al., 2005) and has different coordination numbers $(\mathrm{CN})$ between bridgmanite $(\mathrm{CN}=8$, where it substitutes for Mg; Smyth and Bish, 1988), and silicate melt $(\mathrm{CN}=6$; Farges et al., 1991). Since heavier isotopes tend to concentrate in the phases where it makes tighter bonds it is likely that crystallisation of bridgmanite from a melt would leave the residual liquid enriched in the heavier isotopes compared to bulk mantle.

\section{Samples and Methods}

Thirty one komatiite samples (olivine- and pyroxene-spinifextextured and olivine cumulates) were studied (Table S-1). The komatiite samples are from Fennoscandia (Victoria's Lava Lake, Vetreny Belt; Kostomuksha Greenstone Belt), South Africa (Komati, Weltevreden, and Schapenburg Formations of the Barberton Greenstone Belt), Zimbabwe (Belingwe Greenstone Belt) and Canada (Boston Creek Flow, Abitibi Greenstone Belt and Munro Township). All samples have previously been studied for trace and highly siderophile element abundances, ${ }^{186,187} \mathrm{Os}$, ${ }^{142,143} \mathrm{Nd},{ }^{182} \mathrm{~W}$ isotope systematics (Puchtel et al., 1998, 2001, 2005, 2009, 2013, 2016a,b), and for Ca stable isotopes (Amsellem et al., 2019). Two widely available reference materials (BHVO-2 and AGV-2) for which $\mathrm{Zr}$ isotopic compositions have been reported previously (Inglis et al., 2018; Tian et al., 2020) were also analysed.

Given that komatiites have much lower $\mathrm{Zr}$ content than any previously analysed samples, we performed several full replicates (weighing, spike addition, dissolution, chemical separation, mass spectrometry analyses) (see Table S-1). These samples are noted " $R$ " in Table S-1. The Zr isotopic composition was measured using a ThermoFischer Neptune plus MC-ICP-MS at the IPGP as described in Tian et al. (2020). The protocol utilised for $\mathrm{Zr}$ stable isotope measurements was adapted from Inglis et al. (2018) and is reported in Table S-2. The size of columns utilised had to be scaled up and the chemical purification method modified due to the high $\mathrm{Ca} / \mathrm{Zr}$ of komatiites, and the associated risk of $\mathrm{Zr}$ coprecipitation with $\mathrm{Mg}$, Ca fluorides (Tanaka et al., 2003). To do this, the column procedure from Inglis et al. (2018) was reversed. The details of the analytical methods can be found in the Supplementary Information.

\section{Results}

The $\mathrm{Zr}$ isotopic compositions are reported in Table S-1 as:

$\delta^{94 / 90} \mathrm{Zr}=\left[\frac{\left(\frac{{ }^{94} \mathrm{Zr}}{{ }^{90} \mathrm{Zr}}\right)_{\text {sample }}}{\left(\frac{{ }^{94} \mathrm{Zr}}{{ }^{90} \mathrm{Zr}}\right)_{\text {IPGP-Zr }}}-1\right] \times 1000$

There is presently no international $\mathrm{Zr}$ isotopic standard commercially available and the majority of the $\mathrm{Zr}$ isotopic data for rock samples have been reported against the IPGP-Zr standard (calibrated against a variety of geostandards; Inglis et al., 2018; Feng et al., 2020; Guo et al., 2020; Tian et al., 2020). Alternatively, three other standards have been used: zircon GJ-1 for in situ analyses (Zhang et al., 2019), an elemental Zr standard, NIST SRM3169 (Feng et al., 2020) and a standard in development by NIST (Ibañez-Mejia and Tissot, 2019; Tompkins et al., 2020) for bulk measurements. These three standards have been calibrated against the IPGP-Zr standard (Tian et al., 2020).

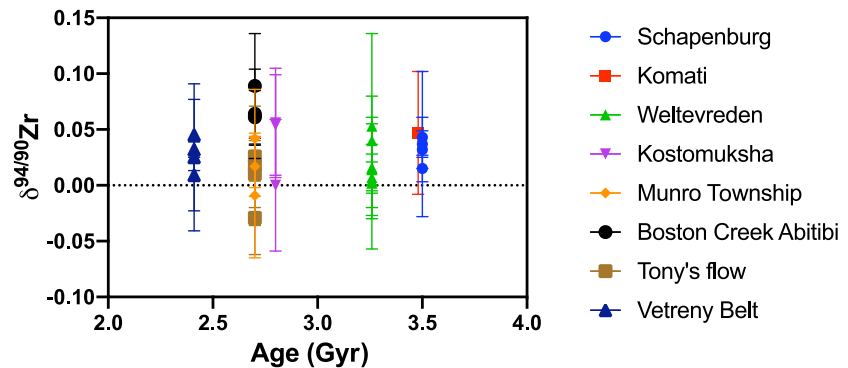

Figure 1 Zirconium isotopic composition of komatiites as a function of their crystallisation ages. The $\delta^{94 / 90} \mathrm{Zr}$ values are constant through $1 \mathrm{Ga}$ and in various locations indicating that the terrestrial mantle had a constant $\delta^{94 / 90} \mathrm{Zr}$ value through time. The Weltevreden komatiites have unusual $\mathrm{Ca}$ isotope signatures consistent with magma ocean crystallisation processes. They do not have a different $Z r$ isotopic composition from other komatiites. Errors as 2 s.d. of replicated measurements (typically 4).

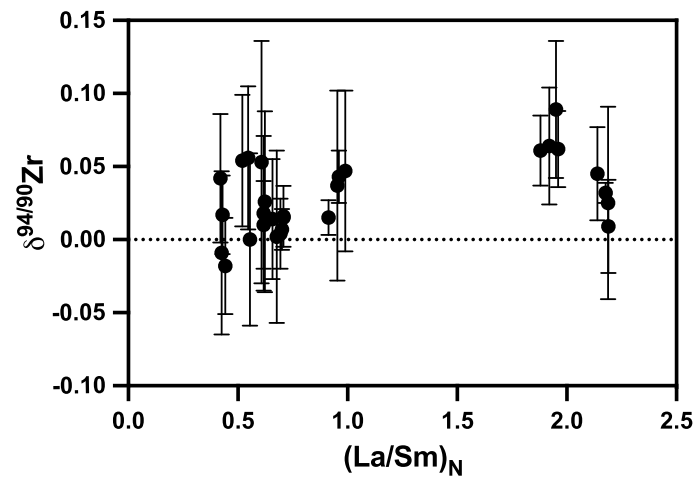

Figure 2 Zirconium isotopic composition of the komatiites as a function of the La/Sm ratio normalised to primitive mantle composition $\left[(\mathrm{La} / \mathrm{Sm})_{N}\right]$. Variations in $(\mathrm{La} / \mathrm{Sm})_{\mathrm{N}}$ are interpreted to reflect prior melt extraction from komatiite source mantles. The absence of variation suggests that prior melt extraction did not fractionate $\mathrm{Zr}$ isotopes and that the source of the komatiites reflects the composition of the Archean mantle. Errors as 2 s.d. of the replicated measurements (typically 4).

The $\delta^{94 / 90} \mathrm{Zr}$ values of $\mathrm{BHVO}-2(0.033 \pm 0.025 \%$ o $)$ and AGV-2 $(0.017 \pm 0.065 \%$ o $)$ are consistent with the previous measurements obtained using a different chemical protocol $\left(\delta^{94 / 90} \mathrm{Zr}=0.044 \pm 0.044 \%\right.$ ond $0.044 \pm 0.050 \%$, respectively $)$, (Inglis et al., 2018) and the values reported in Tian et al. (2020) $(0.045 \pm 0.025 \%$ and $0.035 \pm 0.037 \%$, respectively). Reproducibility of replicate analyses is consistent within the internal error defined by multiple replicate measurements of the same sample solutions. For example, the two replicates of SCH2.6 return a value of $\delta^{94 / 90} \mathrm{Zr}=0.043 \pm 0.018 \%$ o (2 s.d.). In general, the $\mathrm{Zr}$ isotopic compositions of komatiites are relatively invariant, and show no correlation with age (Fig. 1) or the degree of prior melt removal (Fig. 2). The $\delta^{94 / 90} \mathrm{Zr}$ values of all the komatiites range from -0.018 to +0.089 , with an average value of $0.030 \pm 0.04 \%$ o (2 s.d., $\mathrm{n}=31$ ).

\section{Discussion}

No measurable effects on $\mathrm{Zr}$ during magma ocean crystallisation. Based on Os, Nd, Hf, O and Ca isotopic compositions of some komatiites like Weltevreden it has been suggested that they 
recorded the fractionation of minerals stable under magma ocean conditions (Puchtel et al., 2013; Byerly et al., 2017; Amsellem et al., 2019). The source of these komatiites is enriched in the heavier isotopes of $\mathrm{Ca}$, consistent with the extraction of light $\mathrm{Ca}$ in Ca perovskite into the lower mantle and the preservation of mantle heterogeneity until at least the extraction of the komatiites at 3.26 Ga (Amsellem et al., 2019). Given the compatibility of $\mathrm{Zr}$ in bridgmanite and the $\mathrm{CN}$ differences between bridgmanite and silicate melt outlined previously, crystallisation of bridgmanite could fractionate $\mathrm{Zr}$ isotopes. The Weltevreden komatiites do not have anomalous $\mathrm{Zr}$ isotopic compositions (average $\delta^{94 / 90} \mathrm{Zr}$ value for Weltevreden is $0.019 \pm 0.036 \%$, compared to $0.032 \pm 0.054 \%$ or other komatiites; t test, $\mathrm{p}$ value $=$ 0.19) and, therefore, cannot validate the hypothesis. Assuming magma ocean fractionation effects in the source of Weltevreden komatiites, the absence of $\mathrm{Zr}$ isotopic variations likely reflects limited bridgmanite-melt fractionation, because the difference in $\mathrm{CN}$ at high temperatures was insufficient to induce isotopic fractionation resolvable within analytical uncertainty.

Evolution of the Zr isotopic composition of Earth's mantle. The similarity ( $t$ test, $\mathrm{p}$ value $=0.56$ ) of $\mathrm{Zr}$ isotope composition between spinifex-textured and chilled margin komatiites $\left(\delta^{94 / 90} \mathrm{Zr}=0.027 \pm 0.044 \%, \mathrm{n}=14\right)$ and olivine cumulates $\left(\delta^{94 / 90} \mathrm{Zr}=0.033 \pm 0.054 \%, \mathrm{n}=17\right.$; Table $\left.\mathrm{S}-1\right)$ indicates that there was limited isotopic fractionation during komatiite crystallisation. This is illustrated by the absence of correlation between $\delta^{94 / 90} \mathrm{Zr}$ and $\mathrm{Zr}$ content (Fig. $3, \mathrm{R}^{2}=0.2$ ). Since komatiites are formed at temperatures $>2000 \mathrm{~K}$ (Arndt et al., 2008), isotopic fractionation during partial melting is minimised, and, therefore, they must represent the composition of their source. The sources of komatiites had been variably depleted by prior melt extractions, as evidenced from variations in the ratios of the light and heavy REE. This is exemplified by the normalised La/Sm ratio to the primitive mantle composition, $(\mathrm{La} / \mathrm{Sm})_{\mathrm{N}}$, that deviates from one. Prior melt extraction would also have extracted $\mathrm{Zr}$ from the source and, potentially, fractionated $\mathrm{Zr}$ isotopes. The komatiites analysed here encompass a large range of $(\mathrm{La} / \mathrm{Sm})_{\mathrm{N}}$ values, from 0.44 to 2.2 (Puchtel et al., 1998, 2001, $2005 ; 2009,2013,2016 a, b)$. The absence of correlation $\left(R^{2}=\right.$ $0.2)$ between the $\delta^{94 / 90} \mathrm{Zr}$ values and $(\mathrm{La} / \mathrm{Sm})_{\mathrm{N}}$ (Fig. 2) indicates that the mantle sources of komatiites were not isotopically fractionated by prior melt extractions. The absence of temporal $\delta^{94}$ ${ }^{90} \mathrm{Zr}$ variations from 3.5 to $2.41 \mathrm{Ga}$ (Fig. $1, \mathrm{R}^{2}=0.004$ ) provides further evidence that prior melt extraction did not change the $\mathrm{Zr}$ isotopic composition of the komatiite mantle sources.

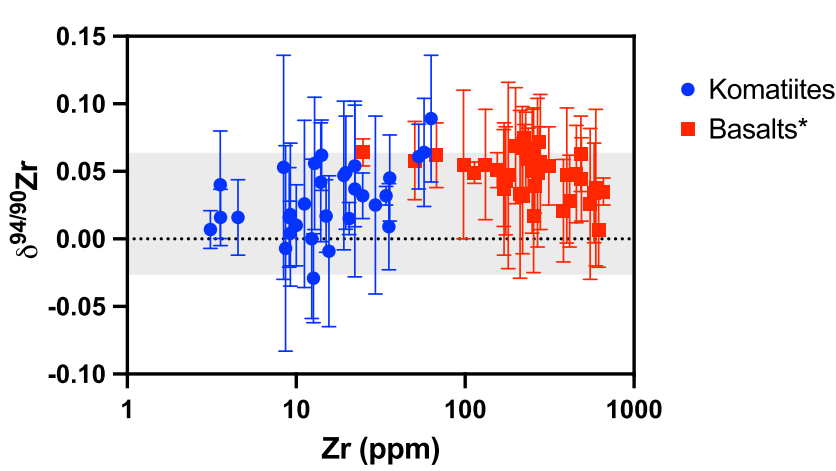

Figure 3 Zirconium isotopic composition of komatiites (this study) and basalts (literature) as a function of the $\mathrm{Zr}$ content of the samples. While $\mathrm{Zr}$ content varies over two orders of magnitude, the $\delta^{94 / 90} \mathrm{Zr}$ are consistent with an average value of $0.040 \pm 0.044$ ( 2 s.d., $n=72$ ), which best reflects the composition of Earth's mantle (grey band). Errors as 2 s.d. of replicate measurements (typically 4). Data from Inglis et al. (2019).
Therefore, the average $\delta^{94 / 90} \mathrm{Zr}$ value of komatiites should reflect the composition of their mantle source. The average $\mathrm{Zr}$ isotopic composition of komatiites $\left(\delta^{94 / 90} \mathrm{Zr}=0.030 \pm 0.049 \%\right.$ o) overlaps with the mantle's estimate based on young basaltic rocks $\left(\delta^{94 / 90} \mathrm{Zr}=0.048 \pm 0.032 \%\right.$ o, Inglis et al., 2019). When averaged together with the previously analysed basalts (Inglis et al., 2019), a conservative estimate for the $\delta^{94 / 90} \mathrm{Zr}$ for the Earth's mantle of $0.040 \pm 0.044 \%$ \% ( 2 s.d., $n=72$ ) is calculated (grey band in Fig. 3). However, it should be noted that basalts are slightly lighter than komatiites ( $t$ test, $p$ value $=0.001$ ), which may indicate that low degree partial melt could be enriched in the heavier isotopes of $\mathrm{Zr}$ as previously suggested to explain the enrichments in light $\mathrm{Zr}$ isotopes in the mantle source of N-MORBs (Inglis et al., 2019). Future analyses of mantle peridotites would allow further assessment of this issue.

\section{Acknowledgements}

We thank three anonymous reviewers and editor A. Shahar for their comments. SYT thanks support from CSC. FM acknowledges an ERC grant \#637503. ISP thanks E. Nisbet, G. Byerly, and $\mathrm{C}$. Anhaeusser for invaluable contributions to his komatiite collection.

\section{Editor: Anat Shahar}

\section{Additional Information}

Supplementary Information accompanies this letter at https:// www.geochemicalperspectivesletters.org/article2033.

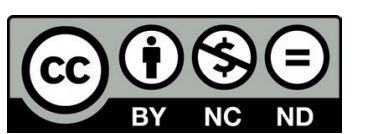

(C) 2020 The Authors. This work is distributed under the Creative Commons Attribution NonCommercial No-Derivatives 4.0 License, which permits unrestricted distribution provided the original author and source are credited. The material may not be adapted (remixed, transformed or built upon) or used for commercial purposes without written permission from the author. Additional information is available at http://www. geochemicalperspectivesletters.org/copyright-and-permissions.

Cite this letter as: Tian, S.Y., Moynier, F., Inglis, E.C., Creech, J., Bizzarro, M., Siebert, J., Day, J.M.D., Puchtel, I.S. (2020) Zirconium isotopic composition of the mantle through time. Geochem. Persp. Let. 15, 40-43.

\section{References}

Amsellem, E., Moynier, F., Puchtel, I.S. (2019) Evolution of the Ca isotopic composition of the mantle. Geochimica et Cosmochimica Acta 258, 195-206.

Arndt, N., Lesher, M., Barnes, S. (2008) Komatiite. Cambridge University Press. Cambridge, New York, Melbourne.

ByerLy, B.L., KAREeM, K., BaO, H., ByerLy, G.R. (2017) Early Earth mantle heterogeneity revealed by light oxygen isotopes of Archaean komatiites. Nature Geoscience 10, 871-875.

CondiE, K.C. (2005) High field strength element ratios in Archean basalts: a window to evolving sources of mantle plumes? Lithos 79, 491-504.

Corgne, A., Liebske, C., Wood, B.J., Rubie, D.C., Frost, D.J. (2005) Silicate perovskite-melt partitioning of trace elements and geochemical signature of a deep perovskitic reservoir. Geochimica et Cosmochimica Acta 69, 485-496.

Deng, Z., Moynier, F., Sossi, P., Chaussidon, M. (2018) Bridging the depleted MORB mantle and the continental crust using titanium isotopes. Geochemical Perspectives Letters 9, 11-15.

Farges, F., Ponader, C.W., Brown JR, G.E. (1991) Structural environments of incompatible elements in silicate glass/melt systems: I. Zirconium at trace levels. Geochimica et Cosmochimica Acta 55, 1563-1574. 
FenG, L., Hu, W., JiaO, Y., Zhou, L., Zhang, W., Hu, Z., Liu, Y. (2020) High-precision stable zirconium isotope ratio measurements by double spike thermal ionization mass spectrometry. Journal of Analytical Atomic Spectrometry 35, $736-745$.

Greber, N.D., Dauphas, N., Puchtel, IS , Hofmann, B.A., Arndt, N.T. (2017) Titanium stable isotopic variations in chondrites, achondrites and lunar rocks. Geochimica et Cosmochimica Acta 213, 534-552.

Guo, J.L., Wang, Z., Zhang, W., Moynier, F., Cui, D., Hu, Z., Ducea, M. (2020) Significant $\mathrm{Zr}$ isotope variations in single zircon grains recording magma evolution history. Proceedings of the National Academy of Sciences, doi: $10.1073 /$ pnas.2002053117

HerzBerg, C. (1992) Depth and degree of melting of komatiite. Journal of Geophysical Research 97, 4521-4540

Hin, R.C., COATH, C.D., CARTeR, P.J., Nimmo, F., Lai, Y.J., POgGe von Strandmann, P.A.E., Willbold, M., Leinhardt, Z.M., Walter, M.J., ELLIOTT, T. (2017) Magnesium isotope evidence that accretional vapour loss shapes planetary compositions. Nature 549, 511-515.

IBAÑEz-MejIA, M., Tissot, F.L. (2019) Extreme Zr stable isotope fractionation during magmatic fractional crystallization. Science Advances 5, eaax8648.

Inglis, E.C., Creech, J.B., Deng, Z., Moynier, F. (2018) High-precision zirconium stable isotope measurements of geological reference materials as measured by double-spike MC-ICPMS. Chemical Geology 493, 544-552.

Inglis, E., Moynier, F., Creech, J., Deng, Z., Day, J.M.D., Teng, F.-Z., Bizzarro, M., JACKSON, M.J., SAVAGE, P. (2019) Isotopic fractionation of zirconium during magmatic differentiation and the stable isotope composition of the silicate Earth. Geochimica et Cosmochimica Acta 250, 311-323.

JoHnson, K.T. (1998) Experimental determination of partition coefficients for rare earth and high-field-strength elements between clinopyroxene, garnet, and basaltic melt at high pressures. Contributions to Mineralogy and Petrology 133, 60-68.

Kato, C., Moynier, F., Foriel, J., Teng, F., Puchtel, I.S. (2017) The gallium isotopic composition of the bulk silicate Earth. Chemical Geology 448, 164-172.

LODDERS, K. (2003) Solar System abundances and condensation temperatures of the elements. Astrophysical Journal 591, 1220-1247.

Moynier, F., VAnce, D., FujI, T., Savage, P. (2017) The isotope geochemistry of copper and zinc. In: Teng, F.-Z., Watkins, J., Dauphas, N. (Eds.) Reviews in Mineralogy \& Geochemistry 82, 543-600.

Pringle, E.A., Moynier, F., Savage, P.S., Badro, J., Barrat, J.A. (2014) Silicon isotopes in angrites and volatile loss in planetesimals. Proceedings of the National Academy of Science USA 111, 17029-32.

Puchtel, I., Hofmann, A., Mrzger, K., Jochum, K., Shchipansky, A., Samsonov, A. (1998) Oceanic plateau model for continental crustal growth in the Archaean: a case study from the Kostomuksha greenstone belt, NW Baltic Shield. Earth and Planetary Science Letters 155, 57-74.

Puchtel, I.S., Brügmann, G.E., Hofmann, A.W. (2001) ${ }^{187}$ Os-enriched domain in an Archean mantle plume: evidence from 2.8 Ga komatiites of the Kostomuksha greenstone belt, NW Baltic Shield. Earth and Planetary Science Letters 186, 513-526.

Puchtel, I.S., Brandon, A.D., Humayun, M., Walker, R.J. (2005) Evidence for the early differentiation of the core from Pt-Re-Os isotope systematics of 2.8-Ga komatiites. Earth and Planetary Science Letters 237, 118-134.

Puchtel, I., Walker, R., Brandon, A., Nisbet, E. (2009) Pt-Re-Os and Sm-Nd isotope and HSE and REE systematics of the 2.7Ga Belingwe and Abitibi komatiites. Geochimica et Cosmochimica Acta 73, 6367-6389.

Puchtel, I., Blichert-Toft, J., Touboul, M., Walker, R., Byerly, G., Nisbet, E., ANHAEUSSER, C. (2013) Insights into early Earth from Barberton komatiites: evidence from lithophile isotope and trace element systematics. Geochimica et Cosmochimica Acta 108, 63-90.

Puchtel, I., Touboul, M., Blichert-Toft, J., Walker, R., Brandon, A., Nicklas, R, KuliKov, V., SAmsonov, A. (2016a) Lithophile and siderophile element sys tematics of Earth's mantle at the Archean-Proterozoic boundary: evidence from 2.4Ga komatiites. Geochimica et Cosmochimica Acta 180, 227-255.

Puchtel, I.S., Blichert-Toft, J., Touboul, M., Horan, M.F., Walker, R.J. (2016b) The coupled ${ }^{182} \mathrm{~W}-{ }^{142} \mathrm{Nd}$ record of early terrestrial mantle differentiation. Geochemistry, Geophysics, Geosystems 17, 2168-2193.

RudnICK, R.L., GaO, S. (2003) Composition of the Continental Crust. In: Holland, H.D., TureKian, K.K. (Eds.) Treatise on Geochemistry 3, 1-64.

SMYTH, J.R., BISH, D.L. (1988) Crystal structures and cation sites of the rock-forming minerals. Allen \& Unwin, Boston.

Tanaka, R., Makishima, A., Kitagawa, H., NaKamura, E. (2003) Suppression of Zr, $\mathrm{Nb}$, Hf and Ta coprecipitation in fluoride compounds for determination in Ca-rich materials. Journal of Analytical Atomic Spectrometry 18, 1458-1463.
TIAN, S., INGUS, E CREeCH, J Z ZHANG, W., WANG, Z, HU, Z, LU, Y, MOYNIER, F. (2020) The zirconium stable isotope compositions of 22 geological reference materials, 4 zircons and 3 standard solutions. Chemical Geology, doi: 10.1016/j.chemgeo.2020.119791.

Tompkins, H., Zieman, L., Ibanez-Meija, M., Tissot, F. (2020) Zirconium stable isotope analysis of zircon by MCICP-MS:methods and application to evaluating intra-crystalline zonation in a zircon megacryst. Journal of Analytical Atomic Spectrometry, doi: 10.1039/c9ja00315k.

Woodhead, J., Eggins, S., Gamble, J. (1993) High field strength and transition element systematics in island arc and back-arc basin basalts: evidence for multi-phase melt extraction and a depleted mantle wedge. Earth and Planetary Science Letters 114, 491-504.

Zhang, W., Wang, Z., Moynier, F., Inglis, E., Tian, S., Li, M., Liu, Y., Hu, Z. (2019) Determination of $\mathrm{Zr}$ isotopic ratios in zircons using laser-ablation multiplecollector inductively coupled-plasma mass-spectrometry. Journal of Analytical Atomic Spectrometry 34, 1800-1809. 